\title{
Feeding protein supplements in alfalfa hay-based lactation diets improves nutrient utilization, lactational performance, and feed efficiency of dairy cows ${ }^{1}$
}

\author{
K. Neal, ${ }^{*}$ J.-S. Eun, ${ }^{2}$ A. J. Young, ${ }^{*}$ K. Mjoun,, and J. O. Hall* \\ *Department of Animal, Dairy, and Veterinary Sciences, Utah State University, Logan 84322 \\ †Alltech, Brookings, SD 57006
}

\begin{abstract}
Due to the increasing cost of soybean meal and concerns of excess $\mathrm{N}$ being excreted into the environment, new protein supplements have been developed. Two products that have shown potential in increasing $\mathrm{N}$ utilization efficiency are slow-release urea (SRU; Optigen; Alltech Inc., Nicholasville, KY) and ruminalescape protein derived from yeast (YMP; DEMP; Alltech Inc.). The objective of this study was to assess the effects of feeding these 2 supplements in alfalfa hay-based [ $45.7 \%$ of forage dietary dry matter (DM)] dairy diets on nutrient utilization, feed efficiency, and lactational performance of dairy cows. Twelve multiparous dairy cows were used in a triple $4 \times 4$ Latin square design with one square consisting of ruminally cannulated cows. Treatments included (1) control, (2) SRU-supplemented total mixed ration (SRUT), (3) YMP-supplemented total mixed ration (YMPT), and (4) SRU- and YMP-supplemented total mixed ration (SYT). The control consisted only of a mixture of soybean meal and canola meal in a 50:50 ratio. The SRU and the YMP were supplemented at 0.49 and $1.15 \%$ DM, respectively. The experiment consisted of 4 periods lasting $28 \mathrm{~d}$ each $(21 \mathrm{~d}$ of adaptation and $7 \mathrm{~d}$ of sampling). Cows fed YMPT and SYT had decreased intake of DM, and all supplemented treatments had lower crude protein intake compared with those fed the control. Milk yield tended to have the greatest increase in YMPT compared with the control (41.1 vs. 39.7 $\mathrm{kg} / \mathrm{d}$ ) as well as a tendency for increased milk fat and protein yields. Feed efficiencies based on yields of milk, $3.5 \%$ fat-corrected milk, and energy-corrected milk increased at 10 to $16 \%$ due to protein supplementation. Cows fed protein supplements partitioned less energy toward body weight gain, but tended to partition more energy toward milk production. Efficiency of use of feed
\end{abstract}

\footnotetext{
Received February 7, 2014.

Accepted August 15, 2014.

${ }^{1}$ Approved as Journal Paper Number 8646 of the Utah Agricultural Experiment Station, Utah State University, Logan.

${ }^{2}$ Corresponding author: jseun@usu.edu
}

$\mathrm{N}$ to milk $\mathrm{N}$ increased by feeding SRUT and YMPT, and milk N-to-manure $\mathrm{N}$ ratio increased with YMPT. Overall results from this experiment indicate that replacing the mixture of soybean meal and canola meal with SRU and YMP in alfalfa hay-based dairy diets can be a good approach to improve nutrient utilization efficiencies in lactating dairy cows.

Key words: alfalfa hay-based dairy diet, lactational performance, protein supplement

\section{INTRODUCTION}

Feeding high-forage diets to lactating dairy cows provides many benefits, including increased digestibility as well as decreasing the risk of ruminal acidosis when compared with high-concentrate diets (Broderick, 2003). The Intermountain West (i.e., Utah, Idaho, Wyoming, Montana, and parts of Arizona and Nevada) is unique in that typical lactation dairy diets contain relatively greater alfalfa hay $(\mathbf{A H})$ compared with the Midwestern United States; baled AH commonly provides 50 to $75 \%$ of the dietary forage with total forage levels averaging 45 to $55 \%$ of dietary DM (Holt et al., 2010). With optimal growing conditions, it is not uncommon to feed high-quality $\mathrm{AH}$ with at least 21.3 and $38.3 \%$ of DM as CP and NDF, on average, respectively (Holt et al., 2013). Although feeding AH provides $\mathrm{CP}$ and enough forage NDF to support potential milk production, its CP is extensively broken down in the rumen by microbes, resulting in less-than-optimal microbial CP (MCP) synthesis, increased energy costs to convert ruminal $\mathrm{NH}_{3}-\mathrm{N}$ to urea, and excess $\mathrm{N}$ excretion into the environment (Holt, 2013). Because of the poor utilization of $\mathrm{CP}$ in alfalfa-based diets by the animal (Castillo et al., 2001), a need exists to discover strategies to improve nutrient utilization, including feed $\mathrm{N}$ in lactation rations, especially in the Intermountain West region.

Microbial protein is the main source of protein for dairy cows, providing 50 to $80 \%$ of total absorbable protein with higher concentrations of Met and Lys, the 2 most limiting AA for milk production (NRC, 2001). 
It is important to maintain MCP synthesis by meeting the protein requirement of the cow with the lowest dietary $\mathrm{CP}$ input, while still maintaining the best ratio between RDP and RUP to support milk production and optimize N utilization efficiency (Agle et al., 2010). Alfalfa hay alone is unable to meet these requirements and, therefore, must be supplemented with other protein sources. Soybean meal (SBM) is a common protein source, but because of its high degradability in the rumen as well as its increasing cost, alternative protein supplements have been developed. Urea is a chemically synthesized NPN that can be used to supplement dietary $\mathrm{CP}$, but is quickly and extensively broken down in the rumen, increasing the ammonia concentration rapidly. Alltech Inc. (Nicholasville, KY) has developed 2 commercial protein supplement products: (1) slowrelease urea (SRU; Optigen), which is urea coated in vegetable oil, slowing its release of ammonia, and (2) yeast-derived MCP (YMP; DEMP) with an AA profile that more closely matches the composition of ruminal MCP and presumably flows with the liquid phase of the rumen, allowing for increased absorption of AA in the small intestine (Sabbia et al., 2012). In a recent study, when SRU was added to high-forage dairy diets consisting of $23.7 \%$ corn silage and $27.7 \%$ alfalfa silage of total dietary DM where SRU replaced SBM, there was an increase in milk yield compared with a control diet (35.9 vs. $35.4 \mathrm{~kg} / \mathrm{d}$; Inostroza et al., 2010). However, when the rumen reaches the point of $\mathrm{NH}_{3}-$ $\mathrm{N}$ overflow, adding more RDP will not increase MCP synthesis (Satter and Slyter, 1974). Instead, if a highquality RUP is supplied, and a sufficient amount of RDP already exists, the amount of AA absorbed in the small intestine can be increased, which supports milk production (Santos et al., 1998; Kalscheur et al., 2006). For example, Sabbia et al. (2012) reported improved milk and TS production when SBM was replaced with YMP in high-forage dairy diets. Therefore, SRU and YMP have great potential to improve nutrient utilization and lactational performance when supplemented in lactation diets consisting of a high concentration of $\mathrm{AH}$. The objective of the current study was to test the hypothesis that adding SRU or YMP, or both, to a high-forage lactation diet consisting of a high dietary concentration of $\mathrm{AH}$ would improve $\mathrm{N}$ utilization efficiency and enhance the lactational performance of dairy cows.

\section{MATERIALS AND METHODS}

The dairy cows used in this study were cared for according to the Live Animal Use in Research Guidelines of the Institutional Animal Care and Use Committee at Utah State University (Logan). The study was con- ducted at the Caine Dairy Research Center (Wellsville, UT), Utah State University from October 18, 2012, to April 15, 2013.

\section{Cows, Experimental Design, and Diets}

Twelve multiparous lactating Holstein cows, 4 of which were surgically fitted with rumen cannula, were used. Cows began the experiment averaging $46 \pm 8.1$ DIM. Average BW were $717 \pm 48.9$ and $730 \pm 43.2$ $\mathrm{kg}$ at the beginning and the end of the experiment, respectively.

A $4 \times 4$ Latin square (replicated 3 times) design was used with one square comprising ruminally cannulated cows. The experiment consisted of 4 periods lasting $28 \mathrm{~d}$ each $(21 \mathrm{~d}$ of treatment adaptation and 7 $\mathrm{d}$ of data and sample collection). Within each square, cows were randomly assigned to a sequence of 4 dietary treatments without or with added protein supplements: no supplement as a control, a TMR containing SRU (SRUT), a TMR containing YMP (YMPT), or a TMR containing SRU and YMP (SYT). The SRU was supplemented at $0.49 \% \mathrm{DM}$ in the SRUT and the SYT in order for cows to consume approximately $127 \mathrm{~g} / \mathrm{d}$. The dietary concentration of the SRU was chosen based on a previous lactation study (Inostroza et al., 2010). Slow-release urea has a CP concentration of $256 \%(41 \%$ $\mathrm{N} \times 6.25$ ), which is slightly lower than urea due to the vegetable oil coating of SRU. The YMP was added at $1.15 \% \mathrm{DM}$ in the YMPT and the SYT treatments in order for cows to consume approximately $299 \mathrm{~g} / \mathrm{d}$ (Sabbia et al., 2012). The CP concentration of YMP is $44.0 \%$ and contains $10.9 \% \mathrm{Arg}, 5.1 \% \mathrm{His}, 11.1 \% \mathrm{Ile}$, $17.6 \%$ Leu, $16.0 \%$ Lys, 3.6\% Met, 9.6\% Phe, $10.0 \%$ Thr, $2.9 \%$ Trp, and $13.4 \%$ Val of total EAA (Sabbia et al., 2012). As a total of CP, YMP contains approximately 55 to $60 \%$ insoluble protein (Tricarico et al., 2011 ), and is estimated to have a passage rate of $7 \% / \mathrm{h}$ by NRC (2001). The passage rate for YMP is underestimated by NRC (2001) because YMP has a very similar passage rate to that of the ruminal liquid phase, which can range from 12 (Agle et al., 2010) to 17\%/h (Choi et al., 2002). Isonitrogenous conditions between treatments were maintained by replacing the mixture of SBM and canola meal (SBMCM) at a ratio of 50:50 with the SRU or the YMP, or both (Table 1), and the SBMCM had 74 and 26\% RDP and RUP, respectively, as a percentage of CP. In addition, diets had similar RDP and RUP fractions.

Diets were formulated based on the NRC (2001) recommendations to provide sufficient $\mathrm{NE}_{\mathrm{L}}, \mathrm{MP}$, vitamins, and minerals to produce $40 \mathrm{~kg}$ of milk/d with $3.5 \%$ fat and $3.0 \%$ true protein $(\mathbf{T P})$. Diets were isonitrogenous and isocaloric $\left(\mathrm{NE}_{\mathrm{L}}\right.$ basis), averaging $16.0 \% \mathrm{CP}$ and 
Table 1. Ingredient and chemical composition (\% of DM, unless otherwise noted) of the experimental diets without or with protein supplements fed to lactating Holstein dairy cows $(\mathrm{n}=4)$

\begin{tabular}{|c|c|c|c|c|c|c|}
\hline \multirow[b]{2}{*}{ Item } & \multicolumn{4}{|c|}{ Experimental $\operatorname{diet}^{1}$} & \multirow[b]{2}{*}{ SEM } & \multirow[b]{2}{*}{$P$-value } \\
\hline & Control & SRUT & YMPT & SYT & & \\
\hline \multicolumn{7}{|l|}{ Ingredient } \\
\hline Alfalfa hay & 24.5 & 24.5 & 24.5 & 24.5 & - & - \\
\hline Corn silage & 28.0 & 30.4 & 28.0 & 30.4 & - & - \\
\hline Corn grain (steam-flaked) & 21.0 & 21.0 & 21.0 & 21.0 & - & - \\
\hline Corn DDGS ${ }^{2}$ & 7.87 & 7.87 & 7.87 & 7.87 & - & - \\
\hline Cottonseed (whole) & 5.24 & 5.24 & 5.24 & 5.24 & - & - \\
\hline Beet pulp (shreds) & 5.24 & 5.24 & 5.24 & 5.24 & - & - \\
\hline $\mathrm{SBMCM}^{3}$ & 5.59 & 2.62 & 4.44 & 1.47 & - & - \\
\hline Optigen & - & 0.49 & - & 0.49 & - & - \\
\hline DEMP & - & - & 1.15 & 1.15 & - & - \\
\hline Sodium bicarbonate & 0.52 & 0.52 & 0.52 & 0.52 & - & - \\
\hline Vitamin and mineral mix $^{4}$ & 2.10 & 2.10 & 2.10 & 2.10 & - & - \\
\hline \multicolumn{7}{|l|}{ Chemical composition } \\
\hline DM, \% & 58.3 & 55.4 & 58.9 & 56.7 & 1.27 & 0.23 \\
\hline $\mathrm{OM}$ & 91.2 & 91.3 & 91.6 & 91.2 & 0.23 & 0.61 \\
\hline $\mathrm{CP}$ & 16.3 & 15.5 & 16.2 & 16.0 & 0.52 & 0.72 \\
\hline $\mathrm{RDP}^{5}$ & 8.49 & 8.61 & 8.42 & 8.55 & - & - \\
\hline $\mathrm{RUP}^{5}$ & 7.16 & 7.12 & 7.21 & 7.15 & - & - \\
\hline NDF & 32.2 & 32.1 & 31.7 & 32.9 & 0.67 & 0.67 \\
\hline $\mathrm{ADF}$ & 18.6 & 18.6 & 18.0 & 19.1 & 0.49 & 0.52 \\
\hline Ether extract & $2.86^{\mathrm{b}}$ & $3.48^{\mathrm{a}}$ & $3.85^{\mathrm{a}}$ & $3.73^{\mathrm{a}}$ & 0.150 & $<0.01$ \\
\hline $\mathrm{NFC}^{6}$ & 39.7 & 40.2 & 40.0 & 38.6 & 0.98 & 0.67 \\
\hline $\mathrm{NE}_{\mathrm{L}},{ }^{5} \mathrm{Mcal} / \mathrm{kg}$ & 1.67 & 1.65 & 1.67 & 1.65 & - & - \\
\hline \multicolumn{7}{|c|}{$\overline{\mathrm{a}, \mathrm{b}}$ Means within a row that do not have a common superscript differ at $P<0.05$. } \\
\hline \multicolumn{7}{|c|}{$\begin{array}{l}{ }^{1} \text { Control }=\mathrm{TMR} \text { without protein supplement; SRUT }=\mathrm{TMR} \text { with slow-release urea (Optigen; Alltech Inc., } \\
\text { Nicholasville, KY); YMPT = TMR with yeast-derived microbial protein (DEMP; Alltech Inc.); SYT = TMR } \\
\text { with slow-release urea and yeast-derived microbial protein. }\end{array}$} \\
\hline \multicolumn{7}{|c|}{${ }^{2}$ DDGS $=$ dried distillers grains with solubles. } \\
\hline \multicolumn{7}{|c|}{${ }^{3}$ Mixture of soybean meal and canola meal at a 50:50 ratio on a DM basis. } \\
\hline \multirow{2}{*}{\multicolumn{7}{|c|}{$\begin{array}{l}{ }^{4} \text { Formulated to contain (per } \mathrm{kg} \text { of DM) } 226.7 \mathrm{mg} \text { of Se (from sodium selenite), 9,278.7 mg of Cu (from copper } \\
\text { amino acid complex), } 40,537.4 \mathrm{mg} \text { of } \mathrm{Zn} \text { (from zinc amino acid complex), 38,653.4 mg of Mn (from manganese } \\
\text { amino acid complex), } 552.6 \mathrm{mg} \text { of Co (from cobalt carbonate), 1,234,585.2 IU of vitamin A, 152,808.1 IU of } \\
\text { vitamin D, 3,815.1 IU of vitamin E, and } 295 \mathrm{mg} \text { of Rumensin (Elanco Animal Health, Greenfield, IN). }\end{array}$}} \\
\hline & & & & & & \\
\hline $\mathrm{CP}-\mathrm{NDF}$ & ct & & & & & \\
\hline
\end{tabular}

$1.66 \mathrm{Mcal} / \mathrm{kg}$ of DM, respectively (Table 1). The AH used in our study had a chemical composition of 20.3, 36.0 , and $25.9 \% \mathrm{DM}$ for $\mathrm{CP}, \mathrm{NDF}$, and $\mathrm{ADF}$, respectively, whereas corn silage had a chemical composition of $7.36,39.0$, and $21.1 \% \mathrm{DM}$ for $\mathrm{CP}, \mathrm{NDF}$, and $\mathrm{ADF}$, respectively.

Cows were housed individually in tie-stalls fitted with rubber mattresses covered with straw, allowing free access to water. Cows were individually fed twice daily for ad libitum intake at a level of $110 \%$ of expected daily intake, with $70 \%$ of allotted feed fed at $0600 \mathrm{~h}$ and $30 \%$ fed at 1500 h. Feed offered and refused was recorded daily, and samples taken during the sampling week to determine DMI.

Cows were milked twice daily at 0400 and $1600 \mathrm{~h}$, and milk production was recorded throughout the entire experiment. Milk was sampled for 2 consecutive days (d 22 and 23) during the a.m. and p.m. milkings each period. Milk samples were stored at $4^{\circ} \mathrm{C}$ and preserved with Broad Spectrum Microtabs II (D \& F Control Systems Inc., San Ramon, CA). Individual milk samples were analyzed by the Rocky Mountain DHIA Laboratory (Wellsville, UT) for fat, TP, lactose, and MUN. Milk composition was expressed on weighted milk yield of a.m. and p.m. samples. Milk fat and protein yields were calculated by multiplying milk yield from the respective day by fat and TP concentration of the milk from an individual cow. To convert milk TP to milk N, 6.38 was used as the conversion factor (DePeters and Cant, 1992), and total milk $\mathrm{N}(\mathrm{kg} / \mathrm{d})$ was calculated as milk TP/6.38 + MUN, where milk TP and MUN were expressed as kilograms per day.

Cows were weighed for 2 consecutive days after the a.m. milking and before the a.m. feeding at the beginning and end of each period. These weights were used to calculate the mean BW of cows for each experimental period. Energy utilization was determined by calculating energy for maintenance as $\mathrm{BW}^{0.75} \times 0.08$ 
(NRC, 2001). Energy of BW change was assumed to be $5.114 \mathrm{Mcal} / \mathrm{kg}$ of gain or $4.924 \mathrm{Mcal} / \mathrm{kg}$ of loss (NRC, 2001). Milk energy was calculated as $(0.0929 \times$ milk fat concentration $)+(0.0563 \times$ milk $\mathrm{TP}$ concentration $)$ $+(0.0395 \times$ milk lactose concentration) $(\mathrm{NRC}, 2001)$. Intake of $\mathrm{NE}_{\mathrm{L}}$ was estimated from $\mathrm{DMI}$ and estimated $\mathrm{NE}_{\mathrm{L}}$ contents (NRC, 2001).

\section{Feed Sampling and Analysis}

Samples of AH and corn silage were taken weekly to determine DM content and diets were adjusted accordingly for change in DM concentration. Samples were composited by month, ground to pass a $1-\mathrm{mm}$ screen (standard model 4; Arthur H. Thomas Co., Swedesboro, NJ), and stored for chemical analysis. Samples of TMR and orts were collected from individual cows on d 22 to 28 , composited, dried at $60^{\circ} \mathrm{C}$ for $48 \mathrm{~h}$, and ground as previously described. The DM concentrations of samples were used to calculate intakes of DM and nutrients.

Analytical DM concentration of samples was determined by oven drying overnight at $105^{\circ} \mathrm{C}$, and $\mathrm{OM}$ was determined by ashing at $550^{\circ} \mathrm{C}$ for $5 \mathrm{~h}$ (AOAC International, 2000; method 942.05). Concentration of $\mathrm{CP}$ was determined using an automated $\mathrm{N}$ combustion analyzer [Elementar (Analysensysteme GmbH, Hanau, Germany); AOAC International, 2000; method 968.06]. Concentrations of NDF and ADF were sequentially determined using a fiber analyzer (200/220; Ankom Technology, Macedon, NY) according to the methodology supplied by the company, which is based on the methods described by Van Soest et al. (1991). Sodium sulfite was used in the procedure for NDF determination and pretreated with heat-stable amylase (type XI-A from Bacillus subtilis; Sigma-Aldrich Corp., St. Louis, MO). Ether extract was measured using a fat analyzer [XT20 (Ankom Technology); AOAC International, 2000; method 2003.05].

\section{Ruminal Fermentation Characteristics}

Ruminal $\mathrm{pH}$ was measured continuously starting on d 24 for 2 consecutive days using indwelling $\mathrm{pH}$ meters in the cannulated cows. The Lethbridge Research Centre Ruminal pH Measurement System (LRCpH; Dascor Inc., Escondido, CA), as described by Penner et al. (2006), was used. Before placing the LRCpH system in the rumen, readings in $\mathrm{pH}$ buffers 4 and 7 were recorded. Meters were placed in the rumen, taking a $\mathrm{pH}$ measurement every $30 \mathrm{~s}$, which was stored by the data logger. The LRCpH was removed from the rumen after $48 \mathrm{~h}$ of continuous $\mathrm{pH}$ measurements and washed in $39^{\circ} \mathrm{C}$ water. The daily ruminal $\mathrm{pH}$ data were aver- aged for each minute and summarized as minimum, mean, and maximum $\mathrm{pH}$. Also, when ruminal $\mathrm{pH}$ was less than 5.8, daily episodes, duration (h/d), and area $(\mathrm{pH} \times \min )$ were calculated. The threshold of 5.8 was chosen because it has been previously described by others (Beauchemin and Yang, 2005) to cause ruminal acidosis.

Ruminal contents were sampled from cannulated cows at 0,3 , and $6 \mathrm{~h}$ after the a.m. feeding on $\mathrm{d} 26$ and 27. Approximately $1 \mathrm{~L}$ of ruminal contents was obtained from different locations within the rumen (anterior dorsal, anterior ventral, medial ventral, posterior dorsal, and posterior ventral) and strained through a polyester screen (pore size: $355 \mu \mathrm{m}$; B. \& S. H. Thompson, Ville Mont-Royal, QC, Canada). Five milliliters of the filtered ruminal fluid was added to $1 \mathrm{~mL}$ of $1 \%$ sulfuric acid, and samples were retained for $\mathrm{NH}_{3}-\mathrm{N}$ determination. The concentration of $\mathrm{NH}_{3}-\mathrm{N}$ in the ruminal contents was measured as described by Rhine et al. (1998). Another $5 \mathrm{~mL}$ of filtered ruminal fluid was added to $1 \mathrm{~mL}$ of $25 \%$ meta-phosphoric acid, and the samples were retained for VFA determination. The VFA were quantified using a gas chromatograph (model 5890; Hewlett-Packard Labs, Palo Alto, CA) with a capillary column $(30 \mathrm{~m} \times 0.32 \mathrm{~mm}$ i.d., $1-\mu \mathrm{m}$ phase thickness, Zebron ZB-FAAP; Phenomenex Inc., Torrance, CA) and flame-ionization detection. The oven temperature was $170^{\circ} \mathrm{C}$ held for $4 \mathrm{~min}$, which was then increased by $5^{\circ} \mathrm{C} / \mathrm{min}$ to $185^{\circ} \mathrm{C}$, and then by $3^{\circ} \mathrm{C} / \mathrm{min}$ to $220^{\circ} \mathrm{C}$, and held at this temperature for 1 min. The injector temperature was $225^{\circ} \mathrm{C}$, the detector temperature was $250^{\circ} \mathrm{C}$, and the carrier gas was helium (Eun and Beauchemin, 2007).

\section{Urine Sampling and Analysis}

On d 22 to 24, spot urine samples were collected from each cow at 0600 and $1800 \mathrm{~h}$ for a total of 6 samples per cow (Holt et al., 2013). Using $4 \mathrm{M} \mathrm{HCl}$, urine samples were acidified to $\mathrm{pH}<4.0$ and composited by cow per period. Samples were frozen and stored at $-40^{\circ} \mathrm{C}$. Samples were thawed at a later date for analysis and diluted with 39 parts diluent to 1 part urine. Diluent consisted of $0.202 \%$ sodium 1-heptane sulfonic acid and $0.086 \%$ ammonium dihydrogen phosphate $\left(\mathrm{NH}_{4} \mathrm{H}_{2} \mathrm{PO}_{4}\right)$, and the solution was brought to a $\mathrm{pH}$ of 2.1 using $4 \mathrm{M} \mathrm{HCl}$. Using the ratio of urinary purine derivatives (PD) to creatinine is an accepted way to estimate the MCP flow to the duodenum (Shingfield and Offer, 1998). The PD and creatinine were analyzed using an HPLC instrument (Waters Corp., Milford, MA) according to the procedures of Shingfield and Offer (1999). Creatinine is used as a marker to estimate urine volume (Valadares et al., 1999). An average creatinine output value of 28 
$\mathrm{mg} / \mathrm{kg}$ of BW estimated by Whittet (2004) was used in calculating urine volume. Others have also reported similar creatinine outputs, ranging from 25 to $30 \mathrm{mg} /$ $\mathrm{kg}$ of BW daily (Jones et al., 1990). To estimate the relative differences in $\mathrm{MCP}$ production, the ratio of urinary PD (allantoin and uric acid) to creatinine was used (Shingfield and Offer, 1998). The supply of MCP was estimated based on estimates of urinary excretion of PD according to the method of Chen and Gomes (1992).

\section{Statistical Analysis}

Data were summarized for each cow by measurement period. All data were analyzed with a model that included the fixed effect of dietary treatment using the repeated option (sampling day in production parameters and sampling time for rumen measures) in the mixed-model procedure of SAS (SAS Institute, 2012). Cow and period were the terms of the random statement. Simple, autoregressive 1, and compound symmetry covariance structures were used in the analysis depending on low values for the Akaike information criterion and the Schwartz Bayesian criterion. Data for intakes of DM and nutrients, VFA, and $\mathrm{N}$ utilization were reported using the variance components structure, whereas milk yield was analyzed by the unstructured covariance structure. Data for milk components and efficiency were analyzed using the compound symmetry covariance structure. In addition, data for $\mathrm{NH}_{3}-\mathrm{N}$ were analyzed by the heterogeneous compound symmetry structure. The relationship between $\mathrm{N}$ intake and efficiency of use of feed $\mathrm{N}$ to milk $\mathrm{N}$ was determined by linear regression using PROC REG of SAS.

For all models used, degrees of freedom were estimated with the Kenward-Roger specification in the models. Means were compared using a protected $(P$ $<0.10$ ) least significant difference test. Least squares means are reported throughout. Treatment effects were declared significant at $P<0.05$, and differences were considered to indicate a trend toward significance at $0.05<P<0.10$.

\section{RESULTS AND DISCUSSION}

A large-scale field trial in Wisconsin commercial dairy herds indicated that SRU supplementation was an effective partial substitute for SBM in high-forage diets by increasing milk yield and income over feed cost (Inostroza et al., 2010). Another lactation dairy experiment showed that substitution of SBM with YMP tended to improve $4.0 \% \mathrm{FCM}$ and ECM yields by dairy cows consuming high-forage diets (Sabbia et al., 2012). The positive results reported in these previous studies led us to conduct the present experiment to investigate nutrient metabolism and utilization of dairy cows fed diets based on $\mathrm{AH}$ when supplementing with SRU and YMP.

\section{Diet Composition and Dietary Treatments}

Ingredients and chemical composition of experimental diets are listed in Table 1. All diets contained a high proportion of forages consisting, on average, of $53.7 \%$ of TMR as forage DM with $45.7 \%$ of forage DM from AH. On an RDP basis, $7.1 \mathrm{~g}$ of SBM is equivalent to $1 \mathrm{~g}$ of SRU (Tikofsky and Harrison, 2006) and, consequently, the $\mathrm{N}$ in SRU is more concentrated compared with SBMCM. Treatments SRUT and SYT had 2.4\% more DM from corn silage than the control and YMPT from the increased DM space created by supplementation with SRU. To maintain isonitrogenous concentrations between treatments, the SBMCM was added in decreasing concentrations, as SRU, YMP, or their combination was added to the diets. Although the concentration of ether extract differed between the control and proteinsupplemented diets, the NFC concentration was similar across experimental diets, averaging $39.6 \%$ DM. The increased ether extract concentration due to adding protein supplements may have resulted from the coating material of the protein supplements.

\section{Intake and Milk Production}

Intakes of DM and nutrients decreased when protein supplements were added to the diet (Table 2). Intakes of NDF and ADF were especially decreased in YMPT compared with the control because of the lower DMI in YMPT. Intake of DM as a proportion of BW of cows tended to decrease $(P=0.10)$ with adding protein supplements. The negative effect of protein supplements on DMI observed in this study was unexpected, and the mechanism whereby protein supplements decreased DMI is difficult to explain. Sabbia et al. (2012) fed diets with increasing amounts of YMP, while decreasing amounts of SBM in high-forage diets consisting of $60.5 \%$ forage DM with $41.6 \%$ DM from corn silage and $18.9 \%$ DM from AH. In the study, cows fed with $0,1.14$, 2.28 , and $3.41 \%$ DM of YMP showed a cubic effect on DMI (Sabbia et al., 2012). In contrast to our findings, they observed an increase in DMI in cows fed $1.14 \%$ DM $(300 \mathrm{~g} / \mathrm{d})$ of YMP compared with a control $(0 \%$ YMP; Sabbia et al., 2012). It is known that urea can be fed to lactating dairy cows up to a concentration of $1 \%$ of the total ration without negative effects on DMI (Kertz, 2010). In the current study, SRU was included at a rate of $0.49 \%$ DM in SRUT and SYT, suggesting that supplementing SRU at this rate would not result 
in the decreased DMI. Akay et al. (2004) reported a decrease of $0.90 \mathrm{~kg} / \mathrm{d}$ in DMI when a product similar to SRU was fed to cows replacing SBM, urea, and whole cottonseed in a control diet, while still maintaining similar milk yield. Allen (2000) reported that DMI can decrease with an excess of metabolic fuels when DMI is not limited by gut fill. Cows receiving protein supplements in the current study may have received all necessary nutrients from lower feed intakes, decreasing the DMI. Another possibility may be the effects of the non$\mathrm{N}$ compounds of the protein supplement products, such as vegetable oil as a coating material in SRU. Further research needs to be done to determine the mechanism of regulation of feed intake when alfalfa hay-based diets are supplemented with SRU or YMP, or both.

Cows fed protein supplements tended to increase yields of milk $(P=0.08), 3.5 \% \mathrm{FCM}(P=0.08)$, and
ECM $(P=0.07)$ compared with those fed the control (Table 2). Ipharraguerre and Clark (2005) found that replacing RDP with RUP using various protein sources (SBM, heated SBM, extruded SBM, corn gluten meal, fish meal, and animal meal) increased milk yield by $2.1 \%$ when diets ranged from 16.0 to $17.9 \% \mathrm{CP}$. The greatest response in milk yield due to feeding YMPT suggests that enough RDP from SBMCM and AH was present to maintain MCP synthesis as well as an increasing the supply of Lys and Met absorbed in the small intestine from YMP to support the increase in milk production. Although ether extract concentration was less in control compared with protein-supplemented diets, milk fat concentration $(3.60 \pm 0.152 \%$, on average) was similar across dietary treatment. Concentrations of $\mathrm{TP}$ and lactose averaged $3.05 \pm 0.076$ and $4.90 \pm 0.058 \%$, respectively, and did not differ between

Table 2. Productive performance, BW change, and net energy utilization of lactating Holstein dairy cows fed alfalfa hay-based TMR without or with protein supplements

\begin{tabular}{|c|c|c|c|c|c|c|}
\hline \multirow[b]{2}{*}{ Item } & \multicolumn{4}{|c|}{ Dietary treatment ${ }^{1}$} & \multirow[b]{2}{*}{ SEM } & \multirow[b]{2}{*}{$P$-value } \\
\hline & Control & SRUT & YMPT & SYT & & \\
\hline \multicolumn{7}{|l|}{ Intake, $\mathrm{kg} / \mathrm{d}$} \\
\hline DM & $29.4^{\mathrm{a}}$ & $27.9^{\mathrm{ab}}$ & $26.5^{\mathrm{b}}$ & $27.5^{\mathrm{b}}$ & 0.84 & 0.02 \\
\hline $\mathrm{DM}, \%$ of BW & 3.99 & 3.76 & 3.55 & 3.71 & 0.143 & 0.10 \\
\hline $\mathrm{OM}$ & $26.8^{\mathrm{a}}$ & $25.5^{\mathrm{ab}}$ & $24.3^{\mathrm{b}}$ & $25.1^{\mathrm{b}}$ & 0.79 & 0.03 \\
\hline $\mathrm{CP}$ & $5.00^{\mathrm{a}}$ & $4.48^{\mathrm{b}}$ & $4.23^{\mathrm{b}}$ & $4.46^{\mathrm{b}}$ & 0.179 & 0.01 \\
\hline $\mathrm{NDF}$ & $9.42^{\mathrm{a}}$ & $8.76^{\mathrm{bc}}$ & $8.40^{c}$ & $9.09^{\mathrm{ab}}$ & 0.276 & $<0.01$ \\
\hline $\mathrm{ADF}$ & $5.47^{\mathrm{a}}$ & $5.00^{\mathrm{bc}}$ & $4.75^{\mathrm{c}}$ & $5.29^{\mathrm{ab}}$ & 0.180 & $<0.01$ \\
\hline \multicolumn{7}{|l|}{ Yield, kg/d } \\
\hline Milk & 39.7 & 40.7 & 41.1 & 40.2 & 1.97 & 0.08 \\
\hline $3.5 \% \mathrm{FCM}$ & 38.8 & 41.5 & 42.7 & 41.0 & 2.43 & 0.08 \\
\hline ECM & 39.5 & 41.7 & 43.0 & 41.2 & 2.26 & 0.07 \\
\hline \multicolumn{7}{|l|}{ Milk composition, $\%$} \\
\hline Fat & 3.43 & 3.64 & 3.70 & 3.64 & 0.152 & 0.39 \\
\hline True protein & 3.05 & 3.04 & 3.08 & 3.01 & 0.076 & 0.41 \\
\hline Lactose & 4.90 & 4.90 & 4.90 & 4.91 & 0.058 & 0.99 \\
\hline \multicolumn{7}{|c|}{ Milk component yield, $\mathrm{kg} / \mathrm{d}$} \\
\hline Fat & 1.34 & 1.49 & 1.53 & 1.46 & 0.098 & 0.10 \\
\hline True protein & 1.19 & 1.21 & 1.27 & 1.20 & 0.051 & 0.07 \\
\hline Lactose & 1.95 & 2.00 & 2.05 & 1.97 & 0.119 & 0.25 \\
\hline \multicolumn{7}{|l|}{ Efficiency } \\
\hline Milk yield/DMI & $1.35^{\mathrm{b}}$ & $1.46^{\mathrm{a}}$ & $1.55^{\mathrm{a}}$ & $1.46^{\mathrm{a}}$ & 0.092 & 0.04 \\
\hline $3.5 \%$ FCM yield/DMI & $1.32^{\mathrm{b}}$ & $1.49^{\mathrm{a}}$ & $1.61^{\mathrm{a}}$ & $1.49^{\mathrm{a}}$ & 0.091 & 0.03 \\
\hline ECM yield/DMI & $1.34^{\mathrm{b}}$ & $1.49^{\mathrm{a}}$ & $1.61^{\mathrm{a}}$ & $1.50^{\mathrm{a}}$ & 0.085 & 0.01 \\
\hline \multicolumn{7}{|l|}{ BW } \\
\hline Initial, $\mathrm{kg}$ & 708 & 716 & 722 & 721 & 14.7 & 0.08 \\
\hline Mean, kg & 733 & 727 & 733 & 727 & 14.9 & 0.62 \\
\hline Gain, $\mathrm{kg} / \mathrm{d}$ & $0.76^{\mathrm{a}}$ & $0.27^{\mathrm{b}}$ & $0.27^{\mathrm{b}}$ & $0.08^{\mathrm{b}}$ & 0.174 & 0.04 \\
\hline \multicolumn{7}{|c|}{ Net energy utilization, Mcal/d } \\
\hline Maintenance & 11.3 & 11.2 & 11.3 & 11.2 & 0.17 & 0.64 \\
\hline BW change & $3.97^{\mathrm{a}}$ & $1.41^{\mathrm{b}}$ & $1.36^{\mathrm{b}}$ & $0.40^{\mathrm{b}}$ & 0.883 & 0.04 \\
\hline Milk & 27.4 & 28.3 & 30.0 & 28.0 & 1.39 & 0.08 \\
\hline Total $^{2}$ & 42.7 & 41.0 & 42.7 & 39.6 & 1.56 & 0.17 \\
\hline $\mathrm{NE}_{\mathrm{L}}, \mathrm{Mcal} / \mathrm{kg}$ of DMI & 1.48 & 1.53 & 1.59 & 1.45 & 0.06 & 0.18 \\
\hline
\end{tabular}

${ }^{\mathrm{a}-\mathrm{c}}$ Means within a row that do not have a common superscript differ at $P<0.05$.

${ }^{1}$ Control $=$ TMR without protein supplement; SRUT $=$ TMR with slow-release urea (Optigen; Alltech Inc., Nicholasville, KY); YMPT = TMR with yeast-derived microbial protein (DEMP; Alltech Inc.); SYT = TMR with slow-release urea and yeast-derived microbial protein.

${ }^{2}$ Net energy used for maintenance, BW gain, and milk. 
treatments. Although no differences existed in milk fat and TP concentrations, due to a tendency $(P=0.08)$ for the increase in milk yield and numerical increases in milk fat and TP concentrations with feeding YMPT, cows fed YMPT tended to increase milk fat $(P=0.10)$ and TP yields $(P=0.07)$. Akay et al. (2004) reported a decreased milk protein concentration, but an increase in milk yield of $3.7 \mathrm{~kg} / \mathrm{d}$, resulting in an increased milk protein yield when a similar SRU product to the one tested in this study was supplemented in diets containing $47.5 \%$ forage and $58.5 \%$ concentrate on a DM basis. The authors concluded that the response in milk yield was due to improved MCP synthesis and increased ruminal starch digestion (Akay et al., 2004). Contrary to our results, Inostroza et al. (2010) reported a tendency for milk fat concentration to decrease $(P=0.07)$ when SRU was supplemented compared with the control in high-forage diets. Increasing YMP supplementation tended $(P=0.06)$ to have a quadratic effect on milk fat concentration in high-forage diets containing SBM as the main dietary protein source, resulting in YMP added at $1.14 \%$ DM to have an increased milk fat concentration (3.66\%) compared with a control (3.53\%; Sabbia et al., 2012). Around $50 \%$ of milk fat is synthesized de novo in the mammary gland from varying precursors including dietary Met. It is still unclear why AA affect milk fat synthesis, but it may be due to the effect that Met has on the synthesis of short- and medium-chain FA (NRC, 2001). Also, AA may have a role in hepatic synthesis of chylomicrons and very low-density lipoproteins (NRC, 2001; Guretzky et al., 2006). Concentrations of Lys and Met as a percentage of total EAA in YMP averaged 16.0 and 3.6\% (Sabbia et al., 2012), respectively, whereas ruminal MCP averaged 15.8 and $5.2 \%$ for Lys and Met, respectively (Clark et al., 1992; NRC, 2001). It has been suggested that for an RUP supplement to be effective, its AA composition should complement the AA profile of MCP (Santos et al., 1998). Under negative energy balance, dairy cows are typically unable to eat enough feed to meet their energy requirements, forcing them to mobilize body fat to support production and making it a more critical time for AA supplementation (Schei et al., 2005). Cows fed YMPT consumed less feed, but had more AA available for absorption, suggesting that more Met and Lys from YMP may have been able to escape ruminal fermentation and be absorbed in the small intestine, resulting in the tendencies for increases in yields of milk, milk fat, and TP.

\section{Feed Efficiency, BW, and Net Energy Utilization}

Feed efficiencies based on yields of milk, 3.5\% FCM, and ECM increased when treatments were supplement- ed with SRU or YMP, or both (Table 2). No difference existed in mean BW between treatments, but feeding protein supplements caused less BW gain compared with the control (Table 2). Net energy for maintenance did not differ between treatments averaging 11.2 $\mathrm{Mcal} / \mathrm{d}$, whereas net energy utilized for BW gain was greater in the control $(3.97 \mathrm{Mcal} / \mathrm{d})$ compared with protein-supplemented treatments $(1.06 \mathrm{Mcal} / \mathrm{d}$, on average). Feeding YMPT tended $(P=0.08)$ to have the greatest net energy utilized for milk production. Total $\mathrm{NE}_{\mathrm{L}}$ requirement was not different between treatments, and experimental diets were formulated to contain 1.66 Mcal $/ \mathrm{kg}$ of $\mathrm{NE}_{\mathrm{L}}$, on average. Due to differences in DMI and yields of milk and its components, $\mathrm{NE}_{\mathrm{L}}$ values were lower than predicted (1.51 Mcal $/ \mathrm{kg}$ of DMI).

Feed efficiencies are used to evaluate herd productivity and profitability, and increased feed efficiencies are associated with greater milk yield, loss in body condition, high-quality forages, and improved feed digestibilities (Britt et al., 2003). Protein-supplemented treatments tended $(P=0.08)$ to increase milk yields and had less net energy utilized for BW gain, along with a decrease in DMI compared with the control (Table 2). Vallimont et al. (2011) found that BW and BCS were negatively but strongly correlated with feed efficiency $\left(\mathrm{R}^{2}=-0.64\right.$ and -0.70 , respectively). Cows that lose more BW during lactation are more efficient, but when measuring feed efficiency, the difference between energy from dietary inputs and body tissue mobilization are not differentiated (Connor et al., 2012). This allows for cows that mobilize more body tissue to have greater feed efficiency. Cows fed with SRU or YMP, or both, showed less net energy utilized for BW gain compared with the control (Table 2), suggesting that the cows fed the protein supplements may have mobilized more body tissue to support milk production, resulting in increased feed efficiency. Although SRU and YMP supplementation resulted in similar increases in the feed efficiencies, feeding YMPT caused the greatest responses among protein-supplemented diets.

Noteworthy is that an interaction between source of main forage in lactation diets and stage of lactation can affect feed efficiency when supplementing RUP, such as YMP (Wattiaux and Karg, 2004). For instance, Sabbia et al. (2012) reported no differences in ECM/ DMI between a control diet and a diet supplemented with $1.14 \%$ YMP. In that study, cows in mid to late lactation fed 1.14\% YMP increased BW compared with those fed a control (Sabbia et al., 2012), implying that more dietary energy was used for BW gain instead of milk production, causing no response in feed efficiency. The lack of effect on feed efficiency due to the YMP supplementation may have been caused by diet composition and stage of lactation. Sabbia et al. (2012) fed 
cows a higher proportion of corn silage $(41.6 \%)$ than $\mathrm{AH}(18.9 \%)$, which may have provided more readily fermentable energy from the diet, decreasing the need for body tissue mobilization to support milk production. Additionally, cows in mid to late lactation do not extensively mobilize body tissue energy to support their milk production. In these conditions, protein supplements may have limited effects on nutrient utilization and feed efficiency, which suggests that YMP supplementation may have a different response in cows fed a relatively low concentration of corn silage and when they are in early lactation or under negative energy balance.

The shift in net energy utilization with decreased DMI due to protein supplementation observed in this study suggests that adding protein supplements channeled more absorbed energy substrates and nutrients into the mammary gland, but minimized them to BW gain. In addition, when feed intake decreases, dairy cows typically mobilize body tissue to support their potential milk production, which may have contributed to better utilization of net energy with protein supplementation. In early lactation or low ME intake situations, a greater supply of RUP can be provided to the cow to meet its protein requirement. Although this can increase milk production, it can also in turn increase body tissue mobilization (Schei et al., 2005). Feeding protein-supplemented diets in the current study increased mobilization of body tissue to support milk production, which resulted in increased feed efficiency. It has been suggested that when energy is available with limited AA supply, energy utilization efficiency is decreased for milk production, and more energy is partitioned toward body tissue (Huhtanen, 1998). The control diet may have had enough energy for milk production, but been limited in its AA supply compared with YMPT, causing the decrease in milk production and the increase in net energy utilized for BW. Caution should be exercised to extrapolate overall data of BW and net energy utilization in the current study due to the short length of data collection and, therefore, further investigation is needed to confirm our data with a relatively long period of experiment.

\section{Ruminal Fermentation Characteristics}

Feeding SYT tended to decrease mean and maximum $\mathrm{pH}$ in the rumen $(P=0.06$; Table 3$)$; however, mean $\mathrm{pH}$ from all dietary treatments were at least above 5.80, which was expected, as we fed a high proportion of forages. An in vitro study performed by Sabbia et al. (2012) resulted in no differences in ruminal pH (averaging $6.46 \pm 0.02$ ) when increasing amounts of YMP replaced SBM. The authors observed similar results in vivo, with ruminal $\mathrm{pH}$ averaging $6.42 \pm 0.51$ when cows were fed the same treatments tested in vitro (Sabbia et al., 2012). No responses in ruminal $\mathrm{pH}$ were detected when rumen-simulating fermentors were offered $50 \%$ forage diets consisting of $25 \%$ corn silage and $25 \% \mathrm{AH}$ (DM basis) with either urea or SRU supplementation (Tikofsky and Harrison, 2006). These results indicate that there would be minimal effects on physiological conditions of ruminal microbial fermentation when SRU or YMP, or both, are supplemented in alfalfa haybased diets.

Cows fed protein-supplemented diets tended to decrease total VFA concentration $(P=0.07)$ compared with those fed the control (Table 3). Feeding SRUT decreased molar proportion of propionate, which contributed to a tendency to increase (acetate + butyrate):propionate $(P=0.08)$. It is unclear why feeding SRUT decreased the propionate proportion compared with the control. Holder (2012) also reported a decreased propionate proportion when growing Holstein steers were fed SRU at $12.1 \%$ CP. Sabbia et al. (2012) reported no differences in total VFA concentration and individual VFA proportions, except for decreased isovalerate when increasing amounts of YMP were supplemented in high-forage diets.

\section{Utilization of $\mathbf{N}$}

Because of decreases in DMI with added protein supplements, $\mathrm{N}$ intake decreased in diets containing SRU or YMP, or both (Table 4). However, feeding YMPT tended $(P=0.09)$ to have the greatest milk $\mathrm{N}$ output, leading to an increase in efficiency of feed N-to-milk $\mathrm{N}$ ratio compared with the control (0.31 vs. 0.25 , respectively). Although decreased $\mathrm{N}$ intake was the main reason for the increased efficiency, the fact that YMP is able to escape ruminal fermentation and provide a high-quality AA may have also affected $\mathrm{N}$ efficiency for milk production. However, inconsistent results have been reported in many studies investigating supplementation of varying RUP sources. For instance, supplying different amounts and sources of RUP have been attributed to the depression of MCP synthesis or the inability of the RUP to provide the limiting AA (Cunningham et al., 1996).

Milk N-to-N intake ratio increased when cows were supplemented with SRU or YMP (Table 4), resulting in a negative correlation $\left(\mathrm{R}^{2}=0.45\right)$ between $\mathrm{N}$ intake and milk $\mathrm{N}$ efficiency (Figure 1). These results indicate that cows with less $\mathrm{N}$ intake are more efficient in utilizing the $\mathrm{N}$ and partitioning it toward milk TP production. A body of evidence exists to indicate that milk $\mathrm{N}$ efficiency is decreased when $\mathrm{N}$ intake is increased (Castillo et al., 2000; Kalscheur et al., 2006; Dijkstra et 
Table 3. Ruminal fermentation characteristics of lactating Holstein dairy cows fed alfalfa hay-based TMR without or with protein supplements

\begin{tabular}{|c|c|c|c|c|c|c|}
\hline \multirow[b]{2}{*}{ Item } & \multicolumn{4}{|c|}{ Dietary treatment ${ }^{1}$} & \multirow[b]{2}{*}{ SEM } & \multirow[b]{2}{*}{$P$-value } \\
\hline & Control & SRUT & YMPT & SYT & & \\
\hline Minimum pH & 5.54 & 5.55 & 5.51 & 5.41 & 0.083 & 0.21 \\
\hline Mean pH & 6.27 & 6.34 & 6.25 & 6.09 & 0.066 & 0.06 \\
\hline $\begin{array}{l}\text { Maximum } \mathrm{pH} \\
\mathrm{pH}<5.8\end{array}$ & 7.24 & 7.18 & 7.02 & 6.87 & 0.109 & 0.06 \\
\hline Daily episodes & 23.8 & 15.5 & 17.0 & 20.3 & 10.34 & 0.92 \\
\hline Duration, h/d & 1.45 & 3.27 & 3.32 & 8.70 & 2.475 & 0.17 \\
\hline Area, $\mathrm{pH} \times \min$ & 10.7 & 35.0 & 31.8 & 34.8 & 16.64 & 0.46 \\
\hline Total VFA, $\mathrm{m} M$ & 140 & 134 & 127 & 131 & 4.4 & 0.07 \\
\hline \multicolumn{7}{|l|}{ Individual $\mathrm{VFA}^{2}$} \\
\hline Acetate (A) & 59.3 & 60.6 & 59.7 & 59.2 & 1.20 & 0.22 \\
\hline Propionate $(\mathrm{P})$ & $25.5^{\mathrm{a}}$ & $24.1^{\mathrm{b}}$ & $25.3^{\mathrm{ab}}$ & $26.0^{\mathrm{a}}$ & 1.43 & 0.05 \\
\hline Butyrate (B) & 11.2 & 11.5 & 11.1 & 10.8 & 0.34 & 0.38 \\
\hline Valerate & $1.66^{\mathrm{a}}$ & $1.46^{\mathrm{b}}$ & $1.51^{\mathrm{b}}$ & $1.69^{\mathrm{a}}$ & 0.087 & $<0.01$ \\
\hline Isobutyrate & 0.82 & 0.77 & 0.82 & 0.80 & 0.071 & 0.83 \\
\hline Isovalerate & 1.21 & 1.39 & 1.43 & 1.29 & 0.130 & 0.17 \\
\hline$(A+B): P$ & 2.80 & 3.05 & 2.86 & 2.79 & 0.210 & 0.08 \\
\hline
\end{tabular}

${ }^{\mathrm{a}, \mathrm{b}}$ Means within a row that do not have a common superscript differ at $P<0.05$.

${ }^{1}$ Control $=$ TMR without protein supplement; SRUT $=$ TMR with slow-release urea (Optigen; Alltech Inc., Nicholasville, KY); YMPT = TMR with yeast-derived microbial protein (DEMP; Alltech Inc.); SYT $=$ TMR with slow-release urea and yeast-derived microbial protein.

${ }^{2}$ Expressed as mol/100 mol.

al., 2013). Castillo et al. (2000) reported that a positive relationship existed between $\mathrm{N}$ intake and milk $\mathrm{N}$ up to $400 \mathrm{~g}$ of $\mathrm{N}$ intake/d, but above $400 \mathrm{~g}$ of $\mathrm{N}$ intake/d, a negative relationship existed. Jonker et al. (2002) reported that every additional gram of $\mathrm{N}$ in the diet over the recommendation decreases $\mathrm{N}$ utilization efficiency by 0.05 percentage units.
The concentration of MUN increased when SRU was supplemented in the diet and was the greatest in SYT (Table 4). Inostroza et al. (2010) also reported an increase in MUN concentration from 12.4 to 13.2 $\mathrm{mg} / 100 \mathrm{~mL}$ for the control and SRU-containing diets, respectively. Wattiaux et al. (2005) reported that MUN concentrations between 10 to $14 \mathrm{mg} / 100 \mathrm{~mL}$ are nor-

Table 4. Nitrogen utilization of lactating Holstein dairy cows fed alfalfa hay-based TMR without or with protein supplements

\begin{tabular}{|c|c|c|c|c|c|c|}
\hline \multirow[b]{2}{*}{ Item } & \multicolumn{4}{|c|}{ Dietary treatment ${ }^{1}$} & \multirow[b]{2}{*}{ SEM } & \multirow[b]{2}{*}{$P$-value } \\
\hline & Control & SRUT & YMPT & SYT & & \\
\hline $\mathrm{N}$ intake, $\mathrm{g} / \mathrm{d}$ & $785^{\mathrm{a}}$ & $699^{\mathrm{b}}$ & $675^{\mathrm{b}}$ & $718^{\mathrm{b}}$ & 26.4 & 0.01 \\
\hline Milk N, g/d & 193 & 195 & 204 & 193 & 8.3 & 0.09 \\
\hline Milk N:N intake ${ }^{2}$ & $0.25^{\mathrm{b}}$ & $0.28^{\mathrm{a}}$ & $0.31^{\mathrm{a}}$ & $0.27^{\mathrm{ab}}$ & 0.016 & 0.03 \\
\hline MUN, mg/100 mL & $12.2^{\mathrm{b}}$ & $13.3^{\mathrm{ab}}$ & $12.4^{\mathrm{b}}$ & $13.7^{\mathrm{a}}$ & 0.52 & 0.01 \\
\hline $\mathrm{NH}_{3}-\mathrm{N},{ }^{3} \mathrm{mg} / 100 \mathrm{~mL}$ & 7.88 & 9.88 & 7.52 & 9.06 & 1.528 & 0.10 \\
\hline Urinary $\mathrm{N}$ excretion, ${ }^{4} \mathrm{~g} / \mathrm{d}$ & 233 & 253 & 236 & 260 & 11.7 & 0.08 \\
\hline Fecal N excretion, ${ }^{5} \mathrm{~g} / \mathrm{d}$ & $358^{\mathrm{a}}$ & $269^{\mathrm{b}}$ & $235^{\mathrm{b}}$ & $264^{\mathrm{b}}$ & 26.9 & $<0.01$ \\
\hline Manure $\mathrm{N}$ excretion, ${ }^{6} \mathrm{~g} / \mathrm{d}$ & $592^{\mathrm{a}}$ & $522^{\mathrm{b}}$ & $471^{\mathrm{b}}$ & $524^{\mathrm{b}}$ & 27.9 & 0.01 \\
\hline $\mathrm{UN}: \mathrm{FN}^{7}$ & $0.65^{\mathrm{b}}$ & $0.94^{\mathrm{ab}}$ & $1.00^{\mathrm{a}}$ & $0.98^{\mathrm{a}}$ & 0.117 & 0.04 \\
\hline $\mathrm{MkN}: \mathrm{MaN}^{8}$ & $0.34^{\mathrm{b}}$ & $0.38^{\mathrm{ab}}$ & $0.46^{\mathrm{a}}$ & $0.38^{\mathrm{b}}$ & 0.033 & 0.04 \\
\hline
\end{tabular}

${ }_{\mathrm{a}, \mathrm{b}}$ Means within a row that do not have a common superscript differ at $P<0.05$.

${ }^{1}$ Control $=$ TMR without protein supplement; SRUT $=$ TMR with slow-release urea (Optigen; Alltech Inc., Nicholasville, KY); YMPT = TMR with yeast-derived microbial protein (DEMP; Alltech Inc.); SYT $=$ TMR with slow-release urea and yeast-derived microbial protein.

${ }^{2}$ Efficiency of use of feed $\mathrm{N}$ to milk $\mathrm{N}$.

${ }^{3}$ Ruminal $\mathrm{NH}_{3}-\mathrm{N}$

${ }^{4}$ Predicted using the following equation: $0.026 \times \mathrm{MUN}(\mathrm{mg}) / 100 \mathrm{~mL} \times \mathrm{BW}(\mathrm{kg})$ (Wattiaux and Karg, 2004).

${ }^{5}$ Predicted using the following equation: $\mathrm{N}$ intake $(\mathrm{g} / \mathrm{d})$ - urinary $\mathrm{N}$ excretion $(\mathrm{g} / \mathrm{d})-$ milk $\mathrm{N}(\mathrm{g} / \mathrm{d})$.

${ }^{6}$ Manure $\mathrm{N}(\mathrm{g} / \mathrm{d})=$ urinary $\mathrm{N}$ excretion $(\mathrm{g} / \mathrm{d})+$ fecal $\mathrm{N}$ excretion $(\mathrm{g} / \mathrm{d})$.

${ }^{7} \mathrm{UN}: \mathrm{FN}=$ urinary $\mathrm{N}$-to-fecal $\mathrm{N}$ ratio, where urinary $\mathrm{N}$ and fecal $\mathrm{N}$ are expressed in grams per day.

${ }^{8} \mathrm{MkN}: \mathrm{MaN}=$ milk $\mathrm{N}$-to-manure $\mathrm{N}$ ratio, where milk $\mathrm{N}$ and manure $\mathrm{N}$ are expressed in grams per day. 


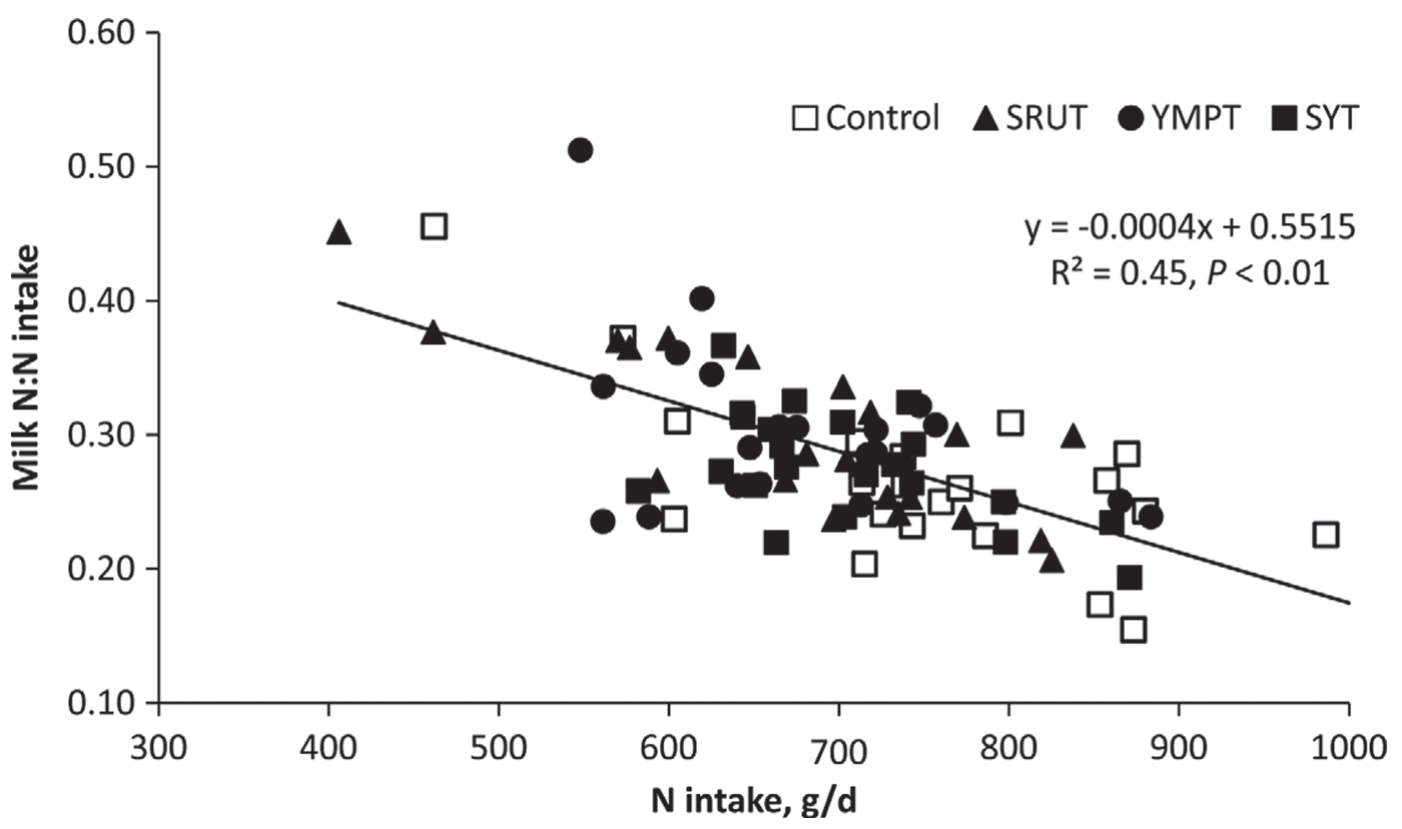

Figure 1. The relationship between $\mathrm{N}$ intake and efficiency of use of feed $\mathrm{N}$ to milk $\mathrm{N}$ (milk $\mathrm{N}: \mathrm{N}$ intake) of lactating Holstein dairy cows fed alfalfa hay-based TMR without or with protein supplements. Control = TMR without protein supplement; SRUT $=$ TMR with slow-release urea (Optigen; Alltech Inc., Nicholasville, KY); YMPT = TMR with yeast-derived microbial protein (DEMP; Alltech Inc.); SYT = TMR with slow-release urea and yeast-derived microbial protein. Each point represents a value from $2 \mathrm{~d}$ from each period for an individual cow $(\mathrm{n}=88)$.

mal, and diets at approximately $16.5 \% \mathrm{CP}$ were found to be associated with a MUN concentration of about $12 \mathrm{mg} / 100 \mathrm{~mL}$, which is considered an optimal situation The SRU product tested in the current study is designed to release urea slowly, but its degradation rate has been shown to change depending on the type of diet. For example, Holder (2012) indicated that when SRU was fed to Holstein steers in high-forage diets, the in situ rate and extent of ruminal degradation of SRU was increased compared with a high-concentrate diet. At 24 $\mathrm{h}$, the SRU in the high-forage treatment was about $90 \%$ degraded, whereas the SRU in the high-concentrate ration was only about $80 \%$ degraded (Holder, 2012). The author concluded that the increase in SRU degradation may have been due to the increase in microbes that produce urease. Although $\mathrm{NH}_{3}-\mathrm{N}$ concentration tended to increase $(P<0.10)$ with SRUT compared with the control and YMPT (9.88 vs. $7.70 \mathrm{mg} / 100 \mathrm{~mL}$, respectively), supplementing SRU would not interfere with $\mathrm{N}$ metabolism, as the $\mathrm{NH}_{3}-\mathrm{N}$ concentration was within its typical range at 1.3 to $28.9 \mathrm{mg} / 100 \mathrm{~mL}$ reported in lactating dairy cows (Kang-Meznarich and Broderick, 1981). The lower ruminal $\mathrm{NH}_{3}-\mathrm{N}$ concentration in YMPT compared with SRU-supplemented treatments may be attributed to the fact that YMP acts as an RUP escaping microbial degradation in the rumen.

Urinary $\mathrm{N}$ excretion tended $(P=0.08)$ to increase in SRUT and SYT (Table 4). Feeding protein-supple- mented diets decreased fecal and manure $\mathrm{N}$ excretions compared with the control. Urinary N-to-fecal N ratio increased with protein supplementation, mainly due to a sizable decrease in fecal $\mathrm{N}$ excretion with slight effect on urinary $\mathrm{N}$ excretion. Urinary $\mathrm{N}$ is known to be the most environmentally volatile N (Varel et al., 1999), because in the environment microbial ureases react with urinary N (Muck, 1982), and then urea is rapidly hydrolyzed to ammonia and volatilized into the environment (James et al., 1999). The tendency $(P=0.08)$ for decreased urinary $\mathrm{N}$ excretion in YMPT demonstrates an additional benefit of YMP supplementation on the environment over SRU supplementation.

Increased milk N-to-manure $\mathrm{N}$ ratio was observed in YMPT (0.46) compared with the control and SYT (0.34 and 0.38, respectively; Table 4). Cows fed the control excreted overall more manure $\mathrm{N}$ because of the increase in DMI compared with the other treatments. As $\mathrm{N}$ intake increases in lactating dairy cows, manure $\mathrm{N}$ output also increases (Yan et al., 2006). A higher milk $\mathrm{N}$-to-manure $\mathrm{N}$ ratio indicates that less manure $\mathrm{N}$ must be managed per unit of milk $\mathrm{N}$ produced by the herd, leading to a desirable $\mathrm{N}$ management practice on farm (Holt et al., 2013). The protein in AH is extensively broken down in the rumen and used inefficiently (Broderick et al., 1992), increasing the risk for excess $\mathrm{N}$ to be released into the environment. However, supplementation of YMP in high-forage diets with a high concentra- 
Table 5. Daily excretion of urinary creatinine, allantoin, uric acid, and estimated ruminal microbial protein production of lactating Holstein dairy cows fed alfalfa hay-based TMR without or with protein supplements

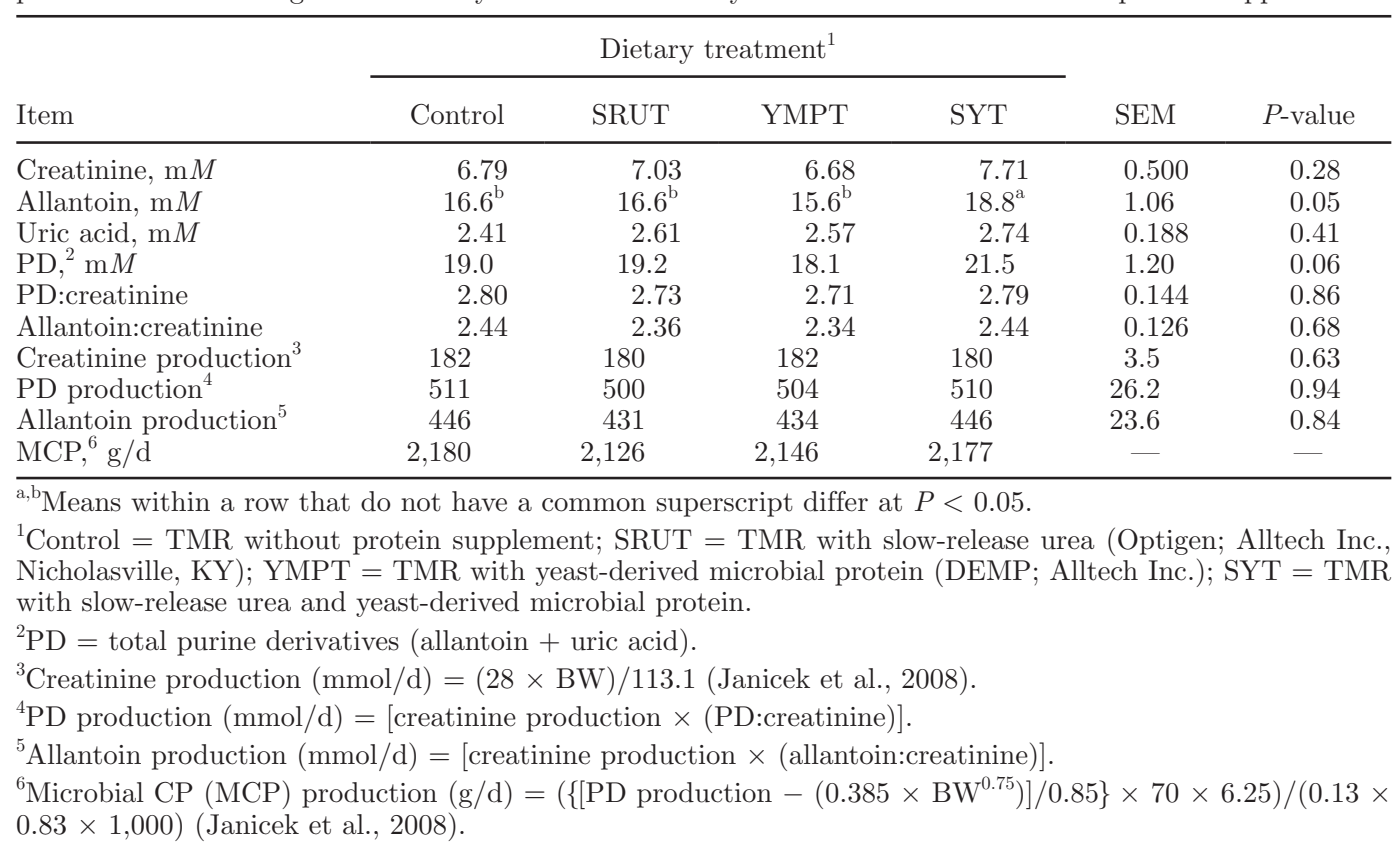

tion of $\mathrm{AH}$ can increase the utilization efficiency of the $\mathrm{N}$ to be converted to milk $\mathrm{N}$ rather than manure $\mathrm{N}$, resulting in positive effects on the environment.

\section{$P D$ and Creatinine Excretion}

The yield of MCP was determined using the production of PD and creatinine, which are reported in Table 5. The concentration of allantoin was increased in SYT compared with all other treatments. The $\mathrm{PD}$ production also had a tendency $(P=0.06)$ to be increased in SYT due to the increase in allantoin concentration compared with all other treatments. The yield of MCP averaged $2,157 \mathrm{~g} / \mathrm{d}$ across treatments. Yield of MCP is determined by 2 factors: the efficiency of utilization of energy from fermented OM by ruminal microbes and total OM fermented in the rumen. Energy-yielding substrates supplied from starches, sugars, fiber, and organic acids are considered to be the most important for MCP yield (Clark et al., 1992). Although cows fed protein-supplemented diets decreased DMI, decreased passage rate of digesta in the rumen may have increased ruminal fermentability of energy-yielding substrate, causing a similar MCP yield across dietary treatments in the current study. Feed intake affects ruminal digestion and passage rate (Yang et al., 2002). When DMI is decreased, passage rate is also decreased, leading to an increase in digestion and influencing MCP synthesis (Shaver et al., 1988).

Ruminal $\mathrm{NH}_{3}-\mathrm{N}$ concentration is a result of balance between production (proteolysis) and assimilation (De
Visser et al., 1997) and, thus, any efforts to maximize $\mathrm{N}$ utilization in the rumen should involve an optimal balance between the 2 metabolic processes. Much debate has occurred about the optimal ruminal $\mathrm{NH}_{3}-\mathrm{N}$ concentration, due to its influence on MCP synthesis. Satter and Slyter (1974) suggested $5 \mathrm{mg}$ of $\mathrm{NH}_{3}-\mathrm{N} / 100 \mathrm{~mL}$ for a safety margin for MCP yield. In contrast, Mehrez et al. (1977) observed that in situ barley DM digestion increased with increasing $\mathrm{NH}_{3}-\mathrm{N}$ concentration until reaching $20 \mathrm{mg} / 100 \mathrm{~mL}$ when urea was infused into the rumen of sheep. Although feeding SRUT decreased intakes of DM and nutrients compared with control in the current study, the increased $\mathrm{NH}_{3}-\mathrm{N}$ concentration with feeding SRUT as well as the potential extra energy from the additional $2.4 \% \mathrm{DM}$ of corn silage may have maintained a similar MCP yield (2,126 vs. 2,180 $\mathrm{g} / \mathrm{d})$. Meanwhile, it may be beneficial to supplement YMP in alfalfa hay-based diets or when cows have low ME intake, because YMP does not require energy to be converted in the rumen to MCP, but rather escapes the rumen in the liquid fraction while still providing the EAA needed for milk production. In a study performed by Maxin et al. (2013), where they compared different protein sources (SBM, canola meal, high-protein dried distillers grains, or wheat dried distillers grains with solubles), no differences were found between treatments in MCP yield (averaging 2,240 $\pm 165.2 \mathrm{~g} / \mathrm{d}$ ). In that study, the authors stated that changes in supply of AA should first be explained by the difference in RUP fraction instead of the effects of MCP synthesis (Maxin et al., 2013). 


\section{CONCLUSIONS}

Greater emphasis has been placed on devising a practical approach to enhancing milk protein production as well as reducing dietary $\mathrm{N}$ wastes in the dairy industry for many years. Although DMI was decreased when SRU and YMP were supplemented in alfalfa hay-based diets, the likely increased supply of AA in YMP during early lactation may allow for more energy to be partitioned toward milk production instead of BW gain, improving milk protein yield, feed efficiency, and overall lactational performance. Also, increased milk N-to-manure $\mathrm{N}$ ratio by feeding YMPT provides a benefit for the environment through better feeding and management programs, while at the same time achieving acceptable $\mathrm{N}$ utilization efficiency and $\mathrm{N}$ excretion. However, we have yet to explore the interactions of AA and energysubstrate metabolism in the mammary gland and whole body, which may contribute to identifying additional evidence for the positive effects of supplementing YMP in alfalfa hay-based lactation diets. We conclude that replacing SBMCM in rations containing a high proportion of AH with YMP during early lactation enhanced nutrient utilization and efficiency, leading to increased milk and milk protein production, and decreased negative environmental impacts.

\section{ACKNOWLEDGMENTS}

The authors thank Alltech (Brookings, SD) for partial financial support of this project as well as running all the $\mathrm{N}$ analysis. Technical assistance provided by J. Miller and W. Burningham at Utah State University (Logan) with the many long hours of sampling and chemical analysis, as well as all the support from the Utah State University Ruminant Nutrition Laboratory is sincerely appreciated. The authors also thank the staff of the Caine Dairy Research Center (Wellsville, UT) for always making sure the experimental animals were well taken care of and their interest in this experiment.

\section{REFERENCES}

Agle, M., A. N. Hristov, S. Zaman, C. Schneider, P. Ndegwa, and V. K. Vaddella. 2010. The effects of ruminally degraded protein on rumen fermentation and ammonia losses from manure in dairy cows. J. Dairy Sci. 93:1625-1637.

Akay, V., J. Tikofsky, C. Holtz, and K. A. Dawson. 2004. Optigen ${ }^{\circledR}$ 1200: Controlled release of non-protein nitrogen in the rumen. Pages 179-185 in Nutritional Biotechnology in the Feed and Food Industries. T. P. Lyons and K. A. Jacques, ed. Nottingham Univ. Press, Nottingham, UK.

Allen, M. S. 2000. Effects of diet on short-term regulation of feed intake by lactating dairy cattle. J. Dairy Sci. 83:1598-1624.

AOAC International. 2000. Official Methods of Analysis. Vol. 1 and 2. 17th ed. AOAC Int., Gaithersburg, MD.
Beauchemin, K. A., and W. Z. Yang. 2005. Effects of physically effective fiber on intake, chewing activity, and ruminal acidosis for dairy cows fed diets based on corn silage. J. Dairy Sci. 88:2117-2129.

Britt, J. S., R. C. Thomas, N. C. Speer, and M. B. Hall. 2003. Efficiency of converting nutrient dry matter to milk in Holstein herds. J. Dairy Sci. 86:3796-3801.

Broderick, G. A. 2003. Effects of varying dietary protein and energy levels on the production of lactating dairy cows. J. Dairy Sci. 86:1370-1381.

Broderick, G. A., S. M. Abrams, and C. A. Rotz. 1992. Ruminal in vitro degradability of protein in alfalfa harvested as standing forage or baled hay. J. Dairy Sci. 75:2440-2446.

Castillo, A. R., E. Kebreab, D. E. Beever, J. H. Barbi, J. D. Sutton, H. C. Kirby, and J. France. 2001. The effect of protein supplementation on nitrogen utilization in lactating dairy cows fed grass silage diets. J. Anim. Sci. 79:247-253.

Castillo, A. R., E. Kebreab, D. E. Beever, and J. France. 2000. A review of efficiency of nitrogen utilisation in lactating dairy cows and its relationship with environmental pollution. J. Anim. Feed Sci. 9:1-32.

Chen, X. B., and M. J. Gomes. 1992. Estimation of microbial protein supply to sheep and cattle based on urinary excretion of purine derivatives - An overview of the technical details. Int. Food. Res. Unit, Occas. Publ. Rowett Res. Inst., Bucksburn, Aberdeen, UK.

Choi, C. W., A. Vanhatalo, S. Ahvenjärvi, and P. Huhtanen. 2002. Effects of several protein supplements on flow of soluble non-ammonia nitrogen from the forestomach and milk production in dairy cows. Anim. Feed Sci. Technol. 102:15-33.

Clark, J. H., T. H. Klusmeyer, and M. R. Cameron. 1992. Microbial protein synthesis and flows of nitrogen fractions to the duodenum of dairy cows. J. Dairy Sci. 75:2304-2323.

Connor, E. E., J. L. Hutchison, K. M. Olson, and H. D. Norman. 2012. Opportunities for improving milk production efficiency in dairy cattle. J. Anim. Sci. 90:1687-1694.

Cunningham, K. D., M. J. Cecava, T. R. Johnson, and P. A. Ludden. 1996. Influence of source and amount of dietary protein on milk yield by cows in early lactation. J. Dairy Sci. 79:620-630.

De Visser, H., H. Valk, A. Klop, J. Van der Meulen, J. G. M. Bakker, and G. B. Huntington. 1997. Nutrient fluxes in splanchnic tissue of dairy cows: Influence of grass quality. J. Dairy Sci. 80:1666-1673.

DePeters, E. J., and J. P. Cant. 1992. Nutritional factors influencing the nitrogen composition of bovine milk: A review. J. Dairy Sci. 75:2043-2070.

Dijkstra, J., C. K. Reynolds, E. Kebreab, A. Bannink, J. L. Ellis, J. France, and A. M. van Vuuren. 2013. Challenges in ruminant nutrition: Towards minimal nitrogen losses in cattle. Pages 47-58 in Energy and Protein Metabolism and Nutrition in Sustainable Animal Production. J. W. Oltjen, E. Kebreab, and H. Lapierre, ed. Wageningen Academic Publishers, Wageningen, the Netherlands.

Eun, J. S., and K. A. Beauchemin. 2007. Enhancing in vitro degradation of alfalfa hay and corn silage using feed enzymes. J. Dairy Sci. 90:2839-2851.

Guretzky, N. A. J., D. B. Carlson, J. E. Garrett, and J. K. Drackley. 2006. Lipid metabolite profiles and milk production for Holstein and Jersey cows fed rumen-protected choline during the periparturient period. J. Dairy Sci. 89:188-200.

Holder, V. B. 2012. The effects of slow release urea on nitrogen metabolism in cattle. PhD Diss. Univ. of Kentucky, Lexington.

Holt, M. S. 2013. Strategic approaches to develop optimal feeding program of brown midrib corn silage to lactating dairy cows in the intermountain west. PhD Diss. Utah State Univ., Logan.

Holt, M. S., K. Neal, J. S. Eun, A. J. Young, J. O. Hall, and K. E. Nestor. 2013. Corn silage hybrid type and quality of alfalfa hay affect dietary nitrogen utilization by early lactating dairy cows. J. Dairy Sci. 96:6564-6576.

Holt, M. S., C. M. Williams, C. M. Dschaak, J. S. Eun, and A. J. Young. 2010. Effects of corn silage hybrids and dietary nonforage fiber sources on feed intake, digestibility, ruminal fermentation, and productive performance of lactating Holstein dairy cows. J. Dairy Sci. 93:5397-5407. 
Huhtanen, P. 1998. Supply of nutrients and productive responses in dairy cows given diets based on restrictively fermented silage. Agric. Food Sci. Finl. 7:219-250.

Inostroza, J. F., R. D. Shaver, V. E. Cabrera, and J. M. Tricárico. 2010. Effect of diets containing a controlled-release urea product on milk yield, milk composition, and milk component yields in commercial Wisconsin dairy herds and economic implications. Prof. Anim. Sci. 26:175-180.

Ipharraguerre, I. R., and J. H. Clark. 2005. Impacts of the source and amount of crude protein on the intestinal supply of nitrogen fractions and performance of dairy cows. J. Dairy Sci. 88:E22-E37.

James, T., D. Meyer, E. Esparza, E. J. Depeters, and H. Perez-Monti. 1999. Effects of dietary nitrogen manipulation on ammonia volatilization from manure from Holstein heifers. J. Dairy Sci. $82: 2430-2439$.

Janicek, B. N., P. J. Kononoff, A. M. Gehman, and P. H. Doane. 2008. The effect of feeding dried distillers grains plus solubles on milk production and excretion of urinary purine derivatives. J. Dairy Sci. 91:3544-3553.

Jones, S. J., D. L. Starkey, C. R. Calkins, and J. D. Crouse. 1990 Myofibrillar protein turnover in feed-restricted and realimented beef cattle. J. Anim. Sci. 68:2707-2715.

Jonker, J. S., R. A. Kohn, and J. High. 2002. Dairy herd management practices that impact nitrogen utilization efficiency. J. Dairy Sci. 85:1218-1226.

Kalscheur, K. F., R. L. Baldwin VI, B. P. Glenn, and R. A. Kohn. 2006. Milk production of dairy cows fed differing concentrations of rumen-degraded protein. J. Dairy Sci. 89:249-259.

Kang-Meznarich, J. H., and G. A. Broderick. 1981. Effects of incremental urea supplementation on ruminal ammonia concentration and bacterial protein formation. J. Anim. Sci. 51:422-431.

Kertz, A. F. 2010. Urea feeding to dairy cattle: A historical perspective and review. Prof. Anim. Sci. 26:257-272.

Maxin, G., D. R. Ouellet, and H. Lapierre. 2013. Effect of substitution of soybean meal by canola meal or distillers grains in dairy rations on amino acid and glucose availability. J. Dairy Sci. 96:7806-7817.

Mehrez, A. Z., E. R. Ørskov, and I. McDonald. 1977. Rates of rumen fermentation in relation to ammonia concentration. Br. J. Nutr. $38: 437-443$.

Muck, R. E. 1982. Urease activity in bovine feces. J. Dairy Sci. 65:2157-2163

NRC. 2001. Nutrient Requirements of Dairy Cattle. 7th rev. ed. Natl. Acad. Sci., Washington, DC.

Penner, G. B., K. A. Beauchemin, and T. Mutsvangwa. 2006. An evaluation of the accuracy and precision of a stand-alone submersible continuous ruminal $\mathrm{pH}$ measurement system. J. Dairy Sci. $89: 2132-2140$

Rhine, E. D., G. K. Sims, R. L. Mulvaney, and E. J. Pratt. 1998. Improving the Bertholot reaction for determining ammonium in soil extracts and water. Soil Sci. Soc. Am. J. 62:473-480.

Sabbia, J. A., K. F. Kalscheur, A. D. Garcia, A. M. Gehman, and J. M. Tricarico. 2012. Soybean meal substitution with a yeastderived microbial protein source in dairy cow diets. J. Dairy Sci. 95:5888-5900.

Santos, F. A. P., J. E. P. Santos, C. B. Theurer, and J. T. Huber. 1998. Effects of rumen-undegradable protein on dairy cow performance: A 12-year literature review. J. Dairy Sci. 81:3182-3213.

SAS Institute. 2012. SAS/STAT User's Guide. Release 9.3. SAS Institute Inc., Cary, NC.
Satter, L. D., and L. L. Slyter. 1974. Effect of ammonia concentration of rumen microbial protein production in vitro. Br. J. Nutr. $32: 199-208$.

Schei, I., H. Volden, and L. Bævre. 2005. Effects of energy balance and metabolizable protein level on tissue mobilization and milk performance of dairy cows in early lactation. Livest. Prod. Sci. 95:35-47.

Shaver, R. D., L. D. Satter, and N. A. Jorgensen. 1988. Impact of forage fiber content on digestion and digesta passage in lactating dairy cows. J. Dairy Sci. 71:1556-1565.

Shingfield, K. J., and N. W. Offer. 1998. Evaluation of the spot urine sampling technique to assess urinary purine derivative excretion in lactating dairy cows. Anim. Sci. 66:557-568.

Shingfield, K. J., and N. W. Offer. 1999. Simultaneous determination of purine metabolites, creatinine and pseudouridine in ruminant urine by reversed-phase high-performance liquid chromatography. J. Chromatogr. B Biomed. Sci. Appl. 723:81-94.

Tikofsky, J., and G. A. Harrison. 2006. Optigen ${ }^{\circledR}$ II: Improving the efficiency of nitrogen utilization in the dairy cow. Pages 373-380 in Nutritional Biotechnology in the Feed and Food Industries. T. P. Lyons and K. A. Jacques, ed. Nottingham Univ. Press, Nottingham, UK.

Tricarico, J. M., K. A. Dawson, and J. D. Johnston. 2011. Ruminant dietary supplement compositions and methods of manufacturing and using the same. Alltech Inc., assignees. US Pat. No. $13 / 028,176$

Valadares, R. F. D., G. A. Broderick, S. C. V. Filho, and M. K. Clayton. 1999. Effect of replacing alfalfa silage with high moisture corn on ruminal protein synthesis estimated from excretion of total purine derivatives. J. Dairy Sci. 82:2686-2696.

Vallimont, J. E., C. D. Dechow, J. M. Daubert, M. W. Dekleva, J. W Blum, C. M. Barlieb, W. Liu, G. A. Varga, A. J. Heinrichs, and C. R. Baumrucker. 2011. Short communication: Heritability of gross feed efficiency and associations with yield, intake, residual intake, body weight, and body condition score in 11 commercial Pennsylvania tie stalls. J. Dairy Sci. 94:2108-2113.

Van Soest, P. J., J. B. Robertson, and B. A. Lewis. 1991. Methods for dietary fiber, neutral detergent fiber, and nonstarch polysaccharides in relation to animal nutrition. J. Dairy Sci. 74:3583-3597.

Varel, V. H., J. A. Nienaber, and H. C. Freetly. 1999. Conservation of nitrogen in cattle feedlot waste with urease inhibitors. J. Anim. Sci. $77: 1162-1168$.

Wattiaux, M. A., and K. L. Karg. 2004. Protein level for alfalfa and corn silage-based diets: I. Lactational response and milk urea nitrogen. J. Dairy Sci. 87:3480-3491.

Wattiaux, M. A., E. V. Nordheim, and P. Crump. 2005. Statistical evaluation of factors and interactions affecting dairy herd improvement milk urea nitrogen in commercial Midwest dairy herds. J. Dairy Sci. 88:3020-3035.

Whittet, K. M. 2004. Factors affecting variability in urinary creatinine and purine derivative excretion in beef cattle. MS Thesis. Univ. of Nebraska, Lincoln.

Yan, T., J. P. Frost, R. E. Agnew, R. C. Binnie, and C. S. Mayne. 2006. Relationships among manure nitrogen output and dietary and animal factors in lactating dairy cows. J. Dairy Sci. 89:3981-3991.

Yang, W. Z., K. A. Beauchemin, and L. M. Rode. 2002. Effects of particle size of alfalfa-based dairy cow diets on site and extent of digestion. J. Dairy Sci. 85:1958-1968. 